ISSN 2524-2369 (Print)

BSSN 2524-2377 (Online)

УДК 398.8+392](476):94(470)“1941/1945”

https://doi.org/10.29235/2524-2369-2020-65-4-467-475

Паступіў у рэдакцыю 29.11.2019

Received 29.11.2019

\title{
Н. А. Гулак
}

Беларускі дзяржаўны ўніверсітэт культуры і мастащтваў, Мінск, Беларусь

\section{АБРОЧНЫ РЫТУАЛ «ХАДЖЭННЕ ХЛЕБА»: МІФАСЕМАНТЫКА І КУЛЬТУРНЫ КАНТЭКСТ}

\begin{abstract}
Аннотация. Представлены уникальные архивные материалы, которые свидетельствуют о распространении в Беларуси в годы Второй мировой войны бытовых магических практик, эсхатологических нарративов и поверий. Научный комментарий фактов народной традиции, зафиксированных советскими исследователями в фольклорно-этнографических экспедициях 1945-1946 гг., свидетельствует о том, что в условиях экстремальной угрозы военного времени в сознании носителей народной культуры актуализировались архаические ритуалы и народно-православные представления. Доказано, что ритуал «хождение хлеба» и распространение «святых писем»- формы ритуальных действий-оберегов - периферийные явления окказиональной обрядности белорусов. Их идейный план определяет синтез народно-религиозных идеологем с элементами контактной, инициальной и апотропейной магии. На акциональном уровне действия-обереги реализовываются как трансмиссионные практики. Концепт войны интерпретируется в них как прорыв хтонического начала в культурное пространство социума, который возможно нейтрализовать только консолидацией его представителей для магической апелляции к высшим силам. Определены мифосемантика, обрядовый контекст и межтекстовые связи ритуала «хождение хлеба». Прослеживается тождественность ключевых моментов ритуала «хождение хлеба» и каравайного обряда. Указаны некоторые явления современной субкультуры православной прихрамовой среды, которые доказывают относительную устойчивость ритуала распространения святого хлеба.

Ключевые слова: Вторая мировая война, ритуал, окказиональная обрядность, «хождение хлеба», «святые письма», мифосемантика, фольклористика

Для цитирования: Гулак, Н. А. Аброчны рытуал «хаджэнне хлеба»: міфасемантыка і культурны кантэкст / Н. А. Гулак // Вес. Нац. акад. навук Беларусі. Сер. гуманіт. навук. - 2020. - Т. 65, № 4. - C. 467-475. https://doi. org/10.29235/2524-2369-2020-65-4-467-475
\end{abstract}

Nastassia A. Hulak

Belarusian State University of Culture and Arts, Minsk, Belarus

\section{SERVAGE RITUAL «BREAD WALKING»: MYTHOSEMANTICS AND CULTURAL CONTEXT}

\begin{abstract}
The article presents unique archival materials providing evidence that everyday magic practices, eschatological narratives and beliefs were common in Belarus during the Second World War. The scientific commentary on the facts registered by Soviet scholars in folklore-ethnographic expeditions of 1945-1946 confirms that during the war archaic rituals and folk orthodox beliefs were actualized in folk culture. It is proved that the ritual "bread walking" and the distribution of "holy letters" belong to the forms of ritualistic amulets. They occupy a peripheral position in the system of occasional rituals of Belarusians. Their ideological content determines the synthesis of folk religious ideologies with elements of contact, initial and apotropic magic. At the stock level, the amulets are implemented as transmission practices. In addition, the work defines mythosemantics, ritual context and intertextual relations of the "bread walking" ritual.

Keywords: Second World War, ritual, occasional rituals, "bread walking", "holy letters", mythosemantics, folklore studies

For citation: Hulak N. A. Servage ritual "bread walking": mythosemantics and cultural context. Vestsi Natsyyanal'nai akademii navuk Belarusi. Seryia humanitarnykh navuk = Proceedings of the National Academy of Sciences of Belarus. Humanitarian Series, 2020, vol. 65, no. 4, pp. 467-475 (in Belarusian). https://doi. org/ 10.29235/2524-2369-2020-65-4-467-475

Уводзіны. У экспедыцыях 1945-1946 гг. супрацоўнікаў сектара этнаграфіi і фальклору Інстытута гісторыі АН БССР на чале з М. Я. Грынблатам былі сабраны ўнікальныя фальклорна-этнаграфічныя матэрыялы, якія сёння ўваходзяць у фонд ІМЭФํ. Пераважную большасць
\end{abstract}

${ }^{1}$ Інстытут мастацтвазнаўства, этнаграфіі і фальклору імя Кандрата Крапівы - філіял ДНУ «Цэнтр даследаванняў беларускай культуры, мовы і літаратуры НАН Беларусі».

(C) Гулак Н. А., 2020 
матэрыялаў, зафіксаваных даследчыкамі ў гэты перыяд, складаюць узоры песеннага рэпертуару ваеннага часу, які бытаваў сярод салдат, партызан і мірнага насельніцтва БССР. Акрамя гэтага, прадстаўлены таксама песні традыцыйнай абраднасці - каляндарныя і сямейныя, нешматлікія апісанні вяселля, тэксты дзіцячага фальклору і інш.

Увагу аўтара прыцягнулі матэрыялы, якія істотна паглыбляюць веды аб рэдкай форме аказіянальнага аброчнага рытуалу - «хаджэнне хлеба». Трэба адзначыць, што аброчны рытуал выпякання і распаўсюджвання хлеба вядомы даследчыкам усходнеславянскай культуры, яго рэфлекс назіраецца і ў сучаснай традыцыі народнай (нізавой) рэлігійнасці. Аднак тэксты, запісаныя падчас першых пасляваенных экспедыцый на Падзвінні і ва Усходнім Палессі, узбагачаюць фонд звестак па аказіянальнай абраднасці беларусаў i, што немалаважна, формах яе бытавання падчас Другой сусветнай вайны. Навуковае каментаванне гэтых тэкстаў выводзіць нас у сферу культурнай антрапалогіі і гісторыі штодзённасці, міфасемантыкі традыцыйнай культуры (персанажны, акцыянальны, атрыбутыўны коды), жанравай прыроды няказкавай фальклорнай прозы.

Асноўная частка. Аб'ём атрыманай інфармацыі дазволіў сфакусіраваць увагу на двух наратывах - дыялектных інтэрпрэтацыях - аброчнага рытуалу «хаджэнне хлеба». Тэкст 1 (гл. дадатак) з'яўляецца мемаратам, зафіксаваным на Усходнім Палессі, у паўночна-ўсходняй частцы Жыткавіцкага раёна, пра што сведчаць тапонімы Бялёу, Пухавічы, Ляхавічы ў тэксце і атрыбуцыі. Мемарат трактуецца як аповед пра падзеі, ён заснаваны на ўласных успамінах носьбіта, у якім адсутнічаюць элементы структурна-сюжэтнага ўзроўню і мастацкі вымысел.

Жанравая прырода тэксту 2 (гл. дадатак) з Падзвіння вызначаецца як гістарычнае паданне. 3 улікам дыскусійнасці праблемы жанравай класіфікацыі няказкавай прозы (працы С. Азбелева, У. Анікіна, У. Пропа, К. Чыстова, І. Галаванава) крытэрыем з'яўляецца адлюстраванне факта мясцовай гісторыі, важнага для інфарматара ў плане захоўвання культурнай памяці. Дадзеная М. Грынблатам назва тэксту “Святы хлеб” і пазначэнне яго жанравай прыналежнасці (сказ, легенда) указваюць на жаданне збіральніка легітымізаваць у тагачаснай фалькларыстыцы гэты надзвычай арыгінальны сюжэт. Факт неадлюстравання вопытным этнографам, якім з'яўляўся М. Грынблат, асаблівасцей паўночна-ўсходняга дыялекту ў мове інфарматара тлумачыцца апасродкаваным шляхам фіксацыі: «Запісай М. Грынблат у 1945 г. у Мінску ад М. Р. Судніка, які чуў ад сваёй маткі Марыі Міхайлаўны Суднік, 47 гадоў, няграматнай з в. Пяиюлёва Ветрынскага c/с Полачкай вобл., праз каторую таксама “хлеб ішоу””». Тапонім «Ветрына»" (Ветрыншчына) і ўказанне ў тэксце на канкрэтную асобу (Якубіха Касароўская, удава) абумоўлены ўстаноўкай інфарматара на сапраўднасць, што з'яўляецца сутнаснай характарыстыкай жанру гістарычнага падання і наогул няказкавай прозы. У тэксце прысутнічае выразны кантамінаваны матыў чарадзейнай казкі: вобраз незнаёмага (едзе з тых месиай, дакуль ужо дайшла вайна) бярэ пачатак ад архетыпа памочніка-дарыльшчыка/продка. Незнаёмы дае веды і цудадзейныя прадметы (заniсачка і тры невялікія булачкі хлеба) у крызісны для супольнасці час. Аналагічныя прыклады матываў цудадзейных памочнікаў-дарыльшчыкаў, а таксама багатырскага каня, уваскрэсення героя і іншыя адзначаны ў вусных аповедах пра Канстанціна Заслонава, зафіксаваных Л. Барагам і М. Меяровіч у першых пасляваенных экспедыцыях [1, с. 190].

У кантэксце даследавання важна адзначыць, што вусныя апісанні абрадаў носьбітамі традыцыі не з'яўляюцца прамой праекцыяй апісваемай практыкі, таму разглядаюцца не як «этнаграфічны факт», а як яго фальклорная эксплікацыя [2, с. 40]. Вызначэнне шырокага міфалагічна-абрадавага кантэксту і міжтэкставых сувязей гэтых фальклорных адзінак суадносіцца 3 аказіянальнай абраднасцю. Сёння вывучэнне аказіянальнай абраднасці беларусаў мае пераважна дэскрыптыўны характар ${ }^{2}$, што тлумачыцца канфігурацыяй развіцця навуковага пазнання ў галіне народнай спадчыны, дзе гэта частка абрадавай культуры працяглы час знаходзілася на перыферыі. Відавочна, фактарамі «перыферыйнасці» былі казуальнасць, неперыядычнасць, неабумоўленасць аказіянальных абрадаў календаром ці жыццёвым цыклам, а таксама вялікая ступень іх сакралізацыі («рытуалы бедства»).

${ }^{1}$ Ветрына - гарадскі пасёлак у Полацкім раёне. Падзеі ваеннага часу ў Ветрына гл.: Смиловицкий Л. Л. Катастрофа евреев в Белоруссии 1941-1944. - Тель-Авив, 2000.

2 Даследаванні М. А. Бабчанок і інш. 
У параўнанні з рытуаламі выклікання дажджу, абворвання вёскі, апаясвання храма найбольш даследаваным у айчыннай навуцы з'яўляецца выраб абыдзённага палатна. Асобныя звесткі пра яго бытаванне ў час Другой сусветнай вайны сустракаюцца ў працы В. Фадзеевай (1994). У гэты час у працэсе працы беларускіх навукоўцаў па стварэнні серыі «Традыцыйная мастацкая культура беларусаў» (далей - ТМКБ) распачынаецца сістэмная фіксацыя наратываў аб абыдзённым рытуале. Апублікаваныя ў тамах ТМКБ 1 і у некаторых іншых працах наратывы, запісаныя В. Лабачэўскай, А. Боганевай, І. Смірновай, Т. Валодзінай, С. Выскваркай, Г. Лапаціным і інш., фактычна ўвялі ў шырокі навуковы і культурны ўжытак архаічны рытуал вырабу абыдзённага палатна. Быў доказна сцверджаны той факт, што ён актуалізаваўся і шырока бытаваў у Беларусі падчас Другой сусветнай вайны.

Канцэптуальнае асэнсаванне рытуалу вырабу абыдзённага палатна як стратэгіі выжывання ва ўмовах экстрэмальнай пагрозы ваеннага часу прадстаўлена ў 2009 г. В. Лабачэўскай. Даследчыца апублікавала рэпрэзентатыўны матэрыял і вызначыла выраб абыдзённага палатна як распаўсюджаную адаптыўную і рэгулятыўную практыку, сродак калектыўнага супрацьстаяння знешнім сілам разбурэння сацыяльнай стабільнасці і культурнай раўнавагі [3, с. 43].

Відавочна, фонд матэрыялаў па гэтай тэме можа ў некаторай ступені павялічвацца, пра што сведчаць сучасныя даследаванні ${ }^{2}[4$, c. $21,46,298]$. Да таго ж некаторыя новыя даныя знаходзяцца ў фальклорных архівах. Напрыклад, у матэрыялах Слуцка-Пінскай экспедыцыі 1946 г. захаваўся запіс М. Я. Грынблата ад 25 жніўня пра ўнікальнае абыдзённае палатно, якое магло прызначацца для апаясвання Свята-Мікалаеўскай царквы ў в. Кажан-Гарадок Лунінецкага раёна. Звяртае на сябе ўвагу адзначаны даследчыкам яго памер: «Абыдзённае палатно каля 40 метраў. Выткана ў вайну, каб бог захаваў ад ваеннай бяды. Знаходзіцца ў Кажан-Гарадоцкай царкве. Абвешаны ўсе сцены» [5, л. 49].

Такім чынам, атрыбутыўны код аказіянальнай абраднасці беларусаў сёння найбольш рэпрэзентуюць прадметы народнага тэкстылю (палатно, намітка, ручнік, кашуля, пояс). Элементамі гэтага кода з'яўляюцца таксама абыдзённыя драўляныя крыжы і рыбалоўныя сеткі. У Беларусі «на дзень св. Аляксея (17/30.ІІІ) рыбакі плялі абыдзённую сетку, каб добра лавілася рыба» [6, с. 489]. Элементам гэтага кода з'яўляецца і абыдзённы хлеб. Павер'е пра яго сустракаецца ў комплексе характэрных для беларускай, украінскай і польскай народнай традыцыі ўяўленняў пра Ваўкалака, у той іх частцы, якая тычыцца сродкаў перасячэння мяжы з хтанічным светам. Абыдзённаму хлебу прыпісваліся магічныя ўласцівасці - вяртаць пярэваратню-ваўкалаку чалавечае аблічча, лекаваць шаленства і іншыя хваробы [6, с. 489]. Звесткі наконт практыкі прыгатавання ў час вайны абыдзённага хлеба разам з вырабам абыдзённай тканіны ў сучаснай вуснай традыцыі адзінкавыя. Гэта можа сведчыць пра тое, што «хлебная аказіянальная абраднасць» мела факультатыўны ў дачыненні да вырабу абыдзённых тканін характар.

Пра трансмісійную практыку «хаджэнне хлеба» сведчаць матэрыялы першых пасляваенных экспедыцый. Так, у 1945 г. адбылася арганізаваная вядучымі саюзнымі ўстановамі пад кіраўніцтвам прафесара П. Багатырова і В. Крупянскай вялікая навуковая экспедыцыя ў Бранскую вобласць РСФСР і сумежныя тэрыторыі БССР, падчас якой былі даследаваны асноўныя цэнтры партызанскага руху на Браншчыне, Смаленшчыне і ў Беларусі. У 1946 г. яе ўдзельніца С. Мінц паведамляла ў часопісе «Советская этнография»: «Запісаны таксама абрад пячэння хлеба і перадачы яго з сяла ў сяло, абрад, які мае на ўвазе патрыятычныя мэты <...>» [7, с. 190].

Можна меркаваць, што менавіта гэтыя матэрыялы трапілі з Дзяржаўнага літаратурнага музея ў Маскве ў архіў Інстытута этналогіі і антрапалогіi РАН і былі выкарыстаны В. Бяловай пры падрыхтоўцы артыкула для этналінгвістычнага слоўніка «Славянские древности»: «Паводле сведчанняў 1940-х гг. з Бранскай вобл., у час вайны па ўсіх дварах у вёсцы збіралі пакрышку

\footnotetext{
${ }^{1}$ Звесткі носьбітаў традыцыі аб бытаванні абыдзённага рытуалу вырабу палатна падчас Другой сусветнай вайны змешчаны ў тамах: Традыцыйная мастацкая культура беларусаў. Т. 3: Гродзенскае Панямонне. Кн. 2. Мінск, 2006; Т. 4: Брэсцкае Палессе. Кн. 2. Мінск, 2009; Т. 5: Цэнтральная Беларусь. Кн. 2. Мінск, 2009; Т. 6: Гомельскае Палессе і Падняпроўе. Кн. 2. Мінск, 2013.

${ }^{2}$ Сумесны навуковы праект даследчыкаў Пскоўскага дзяржаўнага ўніверсітэта і Полацкага дзяржаўнага ўніверсітэта «Традиционный этнокультурный и языковой ландшафт Витебско-Псковского пограничья в конце XIX - начале ХХ в.: уровни репрезентации и динамика кросскультурных связей» (2016).
} 
мукі, пасля малебна ўдовы выпякалі з гэтай мукі тры караваі хлеба і “па часцінках” раздавалі хлеб па дварах. Два караваі неслі ў суседнюю вёску, пасля чаго там паўтараўся той жа рытуал. Лічылася, што як толькі хлябы дасягнуць лініі фронту, вайна скончыцца <... . У іншых варыянтах калектыўны хлеб выпякаўся з цеста, заквашанага на аснове кавалачка каравая, прынесенага “3 манастыра" < .. > “з Кіева"» [8, с. 448].

Сёння ўспаміны пра «хаджэнне хлеба» ў час вайны адзінкавыя. Матэрыял, зафіксаваны ў 2008 г. у Валожынскім раёне В. Лабачэўскай, сведчыць, што інфарматар ужо не памятае мэту гэтай пашыранай у час вайны практыкі:

«Удовы хлеб насілі. Пасля вайны сколька ўдоў пааставалася. Нехта прыдумаў, невядома хто.

$<$ Ад вёскі у вёску хлеб пераносілі і трэба было далей перадаць?>

Аднесці - людзям раздаць. Удовы хлеб насілі. Тут такое прыдумана, а Бог яго ведае, ад чаго?» $[9$, с. 886$]$.

Міфалагічныя канцэпты, якія вызначаюць семантыку і прагматыку рытуалу «хаджэнне хлеба», - гэта ўласна хлеб, вайна і мяжа, з якой звязана лімінальнасиь асноўных суб’ектаў рытуалу. Ciроты круглыя, чэсныля ўдовы, падарожныя асэнсоўваюцца ў традыцыйнай культуры як часткова ці цалкам выключаныя з соцыуму, што абумоўлівае іх медыятыўны статус, здольнасць да кантакту з іншасветам і вызначальную ролю ў «рытуалах бедства».

Паводле А. Байбурына, адным з асноўных спосабаў аб’ектывацыі сэнсу ў абрадавым тэксце з'яўляецца «перавод асноўных ідэй рытуалу на мову прасторавых адносін» [10, с. 183]. У рытуале «хаджэнне хлеба» (тэкст 2) (гл. дадатак) гэта выразна праяўляецца як падзел актуальнай прасторы на сферы свайго і чужога. Рухомая прасторавая мяжа маркіруе прастору па лініі «свой чужы», дзе свая, культурная прастора - гэта вёскі, у тым ліку на акупаванай тэрыторыі, па якіх «ідзе хлеб» (<..> куды не прыдзеш, усюды пякуць. Хлеб ішой иугам, сплашной паласой. Увесь народ памагаў. Адну бабу немщы ледзь не застрэлілі). Чужая, хтанічная прастора - гэта тэрыторыя вайны, якая звужаецца ў выніку пераможнага «наступлення хлеба» (Дайшоў так хлеб да нямеикай граніцы, і вайна скончылася).

Даследчык фенаменалогіi вайны ў сістэме этнічнай культуры беларусаў У. Лобач піша, што «ядравыя кропкі» сэнсапараджэння вайны (ідэалагемы перамога, герой, гвалт, смериь) выяўляюць варыятыўнасць падчас іх прачытання ў розных жанрах фальклору (легендах, тапанімічных паданнях, абрадавых песнях каляндарнага і сямейнага цыклаў), што абумоўлена заканамернасцямі і прагматыкай функцыянавання кожнага жанру [11, с. 62]. Натуральна, гэта датычыць і прачытання самога канцэпту вайны. У міфасемантыцы аброчнага рытуалу «хаджэння хлеба» ён праяўляецца як прарыў хтанічнага свету ў культурную прастору, які магчыма нейтралізаваць усеагульнай кансалідацыяй супольнасці для ментальнай і акцыянальнай апеляцыі да вышэйшых сіл.

Галоўным магічным сродкам супрацьдзеяння хаосу выступае хлеб - штодзённая і абрадавая рэалія, якая мае высокі сакральны статус і дачыненне з якой у вышэйшай ступені рытуалізавана $[12$, с. 412]. Прасочваецца тоеснасць ключавых момантаў аброчнага рытуалу «хаджэння хлеба» і каравайнага абраду, якая выяўляецца ў матыве збірання прадуктаў для галоўнай рытуальнай стравы: ва ўсходнепалескім тэксце адзначаецца, што сіроты круглыя збіралі муку. У вясельнай традыцыі прыгатаванне каравая таксама ўключае збіранне ці складанне каравайніцамі кампанентаў для яго прыгатавання (дроў, прадуктаў). Магічныя ўласцівасці аброчнага хлеба забяспечваюцца сацыяльным і сямейным статусам яго стваральніц (чэсныл ўдовы) i iх калектыўным абраканнем. Таксама і прадукаваная сіла каравая абумоўлена традыцыяй, якая рэгламентуе сам працэс і дапускае да яго канкрэтна вызначаных асоб (замужніх сваячніи, якія маюць дзящей, шчаслівых у шлюбе і інш.). Паводле А. Байбурына, аналогіі паміж выпяканнем хлеба і крэацыйным актам нараджэння якасна новага, рытуальна чыстага аб’екта спрыяе тое, што ў печы холад змяняецца цеплынёй, цемра - святлом, аморфнае цеста робіцца цвёрдым [10, с. 219]. Прыгатаванне хлеба адбываецца ў «жыватворчым кантэксце» саюза агню і вады, што робіць яго здольным уплываць на рэчаіснасць.

Функцыянальнасць вясельнага абрадавага хлеба рэалізуецца праз яго падзел і адорванне часткай кожнага ўдзельніка вяселля, які адначасова выступае і як асоба, і як прадстаўнік сям’i/ 
роду. Аналагічна і функцыянальнасць хлеба ў разглядаемым аброчным рытуале рэалізуецца ў яго распаўсюджанні праз «чэсных удоваў» як рэпрэзентантаў сваёй вясковай супольнасці. Раздаванне аброчнага хлеба (усім па дробi), як і раздаванне вясельнага каравая, бабінай кашы, заснавана на веры ў прадукаваную і апатрапейную моц рытуальнай ежы, якая перадаецца праз магічны кантакт.

Каравайны абрад сумяшчаў у сабе «накіроўваючую» і «дзякавальную» мадэлі абракальнага рытуалу [13, с. 98], яго цыкл быў замкнёны. Такі ж замкнёны цыкл мае месца ва ўсходнепалескіх абрадах Свячы і ў абраднасці Багача, дзе прысутнічаюць выразныя элементы трансмісійных практык - перадача рытуальнага прадмета ў супольнасці ўдзельнікаў. Аброчны рытуал «хаджэння хлеба» разгортваецца толькі па «накіроўваючай» мадэлі, ён транстэмпаральны (пакуль не кончыщиа вайна), а колькасць яго суб'ектаў неабмежаваная.

Тэхналогія прыгатавання хлеба ў разглядаемым аброчным рытуале з'яўляецца вынікам фальклорнага пераасэнсавання практыкі выпякання просвір для праваслаўнай літургіi. Як вядома, просвіра складаецца 3 дзвюх частак, якія вырабляюцца 3 цеста асобна, а потым зляпляюцца. Верхняя частка просвіры $з$ адбіткам крыжа адпавядае духоўнаму пачатку ў чалавеку (Iсусу Хрысту), у той час як ніжняя сімвалізуе зямное, цялеснае. Народны рэцэпт мае прэскрыптыўны характар, у ім акцэнтавана роля верхняй скарыначкі як увасаблення сілы. Абумоўленасць рытуалу «хаджэнне хлеба» праваслаўным царкоўным прадпісаннем пацвярджаецца таксама патрабаваннем ужываць аброчны хлеб нашча, як просвіру, антыдор ці святую ваду. Аднак тое, што ў апісаным рытуале рэцэпт хлеба кіслы, на заквасцы, у той час як для царкоўнай прычасці выкарыстоўваецца хлеб прэсны, сведчыць пра народна-рэлігійную прыроду разглядаемай аброчнай практыкі.

У побытавай культуры праваслаўных аброчныя практыкі былі пашыраным спосабам камунікацыі з сакральным светам, які нёс у сабе пэўным чынам закадзіраваную інфармацыю аб няшчасці ці крызісе [13, с. 98]. Сёння сярод прадстаўнікоў прыхрамавага праваслаўнага асяроддзя працягваюць бытаваць мадыфікаваныя формы трансмісіі святога хлеба пад назвамі ерусалімскі, пачаеўскі, афонскі, Матронін ${ }^{l}$ хлеб ці закваска. Духавенства асуджае практыку распаўсюджання закваскі «святога цеста» ці «цеста шчасця» [14, с. 39-40]. Аргументацыя прадстаўнікоў царквы цікавая ў той частцы, якая сведчыць пра непасрэдную рэплікацыю ў сучаснасці апісваемага намі аброчнага рытуалу часоў вайны: «Самае страшнае, што прапануецца ў рэцэпце, гэта тое, што неабходна раздаць тры часткі цеста 3 чатырох добрым людзям разам з рэцэптам <...> гэта схема раздачы хлеба вельмі падобная на схему распаўсюджання так званых лістоў шчасця, якія не так даўно мелі хаджэнне па ўсёй краіне і нават за мяжой» [15]. Такім чынам, трансмісійная практыка «хаджэння хлеба» з'яўляецца познетрадыцыйнай адносна вырабу абыдзённіка, абыходаў, абворвання, апаясвання, агароджвання, абкурвання формай рытуальнага дзеяння-абярэга, якая працягвае існаваць у сучаснай побытавай культуры праваслаўных.

Яшчэ адной формай дзеяння-абярэга ў экстрэмальнай сітуацыі вайны было перапісванне т. зв. святых пісем: «На Браншчыне падчас вайны перадавалі адзін аднаму і па 6 разоў перапісвалі “пісьмо ад Ісуса Хрыста”, у якім прадказваўся канец вайны. Лічылася, што калі пісьмо пяройдзе лінію фронту, вайна скончыцца» [8, с. 448]. Распаўсюджанне гэтай з’явы ў 1930-я гг. і падчас вайны ўзгадваецца ў працы В. Лур'е і ў некаторых іншых крыніцах. Адзінкавыя звесткі пра святыя nicbмы ў вайну змяшчаюцца ў ТМКБ: «Пісьма нейкія пісалі. Нада за раз напісаць гэна пісьмо і перадаць нескулькі чалавек» [9, с. 886].

Сёння паходжанне і тыпалогія сучаснага ўстойлівага феномена магічных пісем (святыя пicbмы, нябесныл пасланні) даследавана ў працах А. Панчанкі, С. Сміта, Д. Радчанка, Е. Панамаровай, С. Барысава і інш. Вызначана, што гэта з’ява, маючая «надканфесійны» характар, была распаўсюджана ва ўсходнеславянскай, заходнееўрапейскай і англа-амерыканскай культурах і ўяўляе сабой вельмі шырокі спектр рэлігійна-магічных тэкстаў, якія ўключаюць апакрыфічныя казанні і павучанні, пісьмы-абярэгі, кругавыя пісьмы і інш. [16, с. 629]. А. Весялоўскі, які тлумачыў паходжанне гэтай з'явы шырокім распаўсюджаннем на тэрыторыі хрысціянскай Еўропы пераказаў апакрыфічнага павучання аб святкаванні нядзелі, яшчэ ў 1876 г. пісаў, што ў народзе эnic-

\footnotetext{
1 Звязана з імем Матроны Маскоўскай (Пакроўскі стаўрапігіяльны жаночы манастыр, Масква).
} 
толія заўсёды выконвала функцыю амулета, заклінальнай формулы, якая адганяе злых духаў [17, с. 115]. В. Лур'е, разглядаючы з'яву з пазіцый праваслаўнай царквы, указваў на яе эсхаталагічную «ідэалогію» і фатальны прапаведніцкі характар: «Як відаць 3 познетрадыцыйных тэкстаў “святых пісем”, старажытная традыцыя абяцання пакарання, пагроза страшных праклёнаў у разглядаемым жанры пісьмовага фальклору дайшла да нашых дзён»" [18, с. 147].

Нягледзячы на тое, што ў сітуацыі вайны дынаміка народнай рэлігійнасці, у тым ліку распаўсюджання побытавых магічных практык, эсхаталагічных аповедаў і павер'яў узрастала, у фалькларыстыцы такія факты мала адлюстраваны. Даследчыцкі пошук савецкіх вучоных быў скіраваны перадусім на фальклорныя творы іншага ідэйнага зместу. У якасці адзінкавых прыкладаў згадаем былічкі аб вайне з архаічнымі матывамі ваўка, які размаўляе, чараўніка, пеўня, жытняга коласа, запісаныя ўдзельнікамі маскоўскай экспедыцыі 1945 г. на Браншчыне i суседніх тэрыторыях БССР [7, с. 190]. Эсхаталагічныя легенды аб разгроме немцаў і заканчэнні вайны фіксавалі экспедыцыі вучоных АН БССР на Усходнім Палессі ў 1945-1946 гг., аб чым сведчыць фонд тэкставых запісаў фонду ІМЭФ. Напрыклад, сустракаецца наступны запіс: «Бралі краснага і чорнага петуха, сводзілі іх біџиа. Сначала пабедзіў чорны, а у паследствіі урродзі перадыхнулі, красны пабядзіў, то ущжо зналі, - нашы пабедзяць. Сны сніліся, што наша пабеда будзе» (запісаны 25 жніўня 1946 г. у в. Пухавічы Ляхавіцкага с/с Жыткавіцкага р-на ад старой Макарэвіч, маці-гераіні) [5, л. 61]. Прыведзены ўзор няказкавай фальклорнай прозы пра бой пеўняў не з'яўляецца фальклорнай эксплікацыяй «этнаграфічнага факта» i, відавочна, не адлюстроўвае этнаграфічныя рэаліі Беларусі часоў вайны. Своеасаблівы «вандроўны сюжэт» паходзіць са сферы народна-праваслаўнага быту і з'яўляецца тыповым для сялянскага эсхаталагічнага фальклору часоў Другой сусветнай вайны [19, с. 408]. Яго рэдукаваная форма сустракаецца ў легендарна-жыційным комплексе тэкстаў пра кананізаваную старыцу Матрону Маскоўскую (аповеды аб прыездзе да яе Сталіна ўвосень 1941 г. і прадказанні Матронай перамогі савецкіх войскаў у вайне) [20, с. 15$]$.

У прадказанні выніку вайны па бойцы пеўняў перамога чырвонага, натуральна, трактуецца як перамога «нашых», «рускіх», «савецкіх» над «чужымі», «немцамі», «фашыстамі». У большасці тэкстаў, прыведзеных В. Бяловай, хтанічны пачатак увасабляе белы певень [19, с. 408-410]. Семантыка белага колеру пеўня-антаганіста ідэалагічна дэтэрмінаваная: у вуснай традыцыі савецкага чалавека захоўваліся сфарміраваныя савецкай прапагандай 1920-х гг. негатыўныя канатацыі ідэалагем «белагвардзейцы», «белафіны», «белапалякі». Выразная ў славянскай традыцыі ахоўная семантыка чырвонага колеру ўзмоцнена колеравай сімволікай савецкай улады.

У беларускім варыянце чорны колер пеўня-антаганіста з'яўляецца вынікам пазнейшага пераасэнсавання, якое адбылося ў дыскурсе аб Другой сусветнай вайне. Адносна аддаленыя падзеі часоў станаўлення савецкай улады і грамадзянскай вайны паступова страцілі актуальнасць, саступіўшы месца ў масавай культуры вобразу чорнай фашысцкай навалы. Хтанічны пачатак, варожую сілу стаў маркіраваць чорны (иёмны) колер (Вставай, страна огромная, вставай на смертный бой, / С фашистской силой темною, с проклятою ордой), які не ў апошнюю чаргу быў абумоўлены колерам формы нямецкіх салдат. У сэнсе ідэалагічнай дэтэрмінацыі колераў у апакаліптычных наратывах пасляваеннага часу ўяўляе цікавасць узор сюжэта 3 «навелай», народжанай уплывам савецка-кітайскага палітычнага процістаяння 1950-1960-х гг. Прадказваецца прыход «жоўтага пеўня» (Кітая), які ўсіх паб’е і пераможа [19, с. 410].

Высновы. Экстрэмальныя пагрозы ваеннага часу, узмацненне эсхаталагічных чаканняу насельніцтва выклікалі ў традыцыйным грамадстве, як пісаў А. Байбурын, высокую ступень няпэўнасці. Гэта абумоўлівала пашырэнне магічных практык, асаблівую аператыўнасць варожбаў, прыкмет і прафетычных уяўленняў як асноўных інструментаў зніжэння няпэўнасці [10, с. 175]. Відавочна, дынаміка народнай рэлігійнасці, у тым ліку распаўсюджанне рытуалу «хаджэнне хлеба», практыкі перапісвання «святых пісем», у гады вайны ўзрастала. Аднак у савецкай фалькларыстыцы падобныя факты практычна не асэнсаваны, паколькі даследчыцкі пошук савецкіх вучоных скіроўваўся ў першую чаргу на фальклорныя творы героіка-патрыятычнага гучання.

\footnotetext{
${ }^{1}$ Праваслаўная царква ўказвае на іх акультны характар: Мартинович В. А. Письма счастья как элемент оккультной среды общества // Минские епархиальные ведомости. - 2007. - № 1(80). - С. 72-76.
} 
Сёння аналіз нешматлікіх архіўных матэрыялаў экспедыцый 1945-1946 гг. супрацоўнікаў сектара этнаграфіi і фальклору Інстытута гісторыі АН БССР на чале з М. Я. Грынблатам дазваляе сцвярджаць, што фальклорныя эксплікацыі аброчнага рытуалу «хаджэння хлеба» адлюстроўваюць апеляцыю носьбітаў да архаічных узроўняў свядомасці, на міфасемантычным і акцыянальным узроўнях выяўляецца ўстойлівая сувязь рытуалу з усходнеславянскай абрадавай традыцыяй.

«Хаджэнне хлеба» - перыферыйная познетрадыцыйная з'ява аказіянальнай абраднасці беларусаў, падвід аброчных (павінных) рытуалаў, у кантэксце якіх аброк трактуецца як ментальная ўстаноўка носьбітаў традыцыі і як аб’ект рытуальных дзеянняў. Па форме рэалізацыі рытуал 3'яўляецца трансмісійнай практыкай, ідэйны план якой вызначае сінтэз народна-рэлігійных ідэалагем 3 элементамі кантактнай, ініцыяльнай і апатрапейнай магіi. Наратывы пра «хаджэнне хлеба» адлюстроўваюць акцэнтаваную інфарматарамі веру ў эфектыўнасць рытуалу, прэскрыптыўны характар тэхналогіi прыгатавання рытуальнага хлеба і ўзбагачаюць фонд няказкавай фальклорнай прозы часоў Другой сусветнай вайны.

\section{Дадатак}

\section{Тэкст 1}

\section{Як хлеб ішоў}

(У часы вайны пяклі святы хлеб і перадавалі з вёскі ў вёску, каб хутчэй прыйшла перамога над нямецкімі захопнікамі) [рэмарка М. Я. Грынблата].

Сіратом круглым, яны сабіралі муку, а ўдовы пяклі. 3 гэтым хлебам тры разы абыходзілі дзярэўню, ікону бралі. Хлеб сюды прынеслі з Белёва, булачку і бумажку, было напісана, як рабіць. На разыход дарог справілі абедню, раздалі булачку ўсім па дробі. Верхнюю скарыначку клалі ў цёплую ваду, з яе расчынялі новы хлеб, каб наш верх быў над немцам. У старыну як балесь дзе ўваб’ецца у дзярэўню, песні святыя пелі'.

25.08.1946 г. Пухавічы Ляхавіцкага с/с Жыткавіцкага р-на, ад старой Макарэвіч, маці-гераіні. Фонд ІМЭФ. Ф. 8. Воп. 1. Спр. 9. Слуцка-Пінская экспедыцыя 1946 г. Сшытак 2. Запісы М. Я. Грынблата. Лістоў 70. Л. 59.

\section{Тэкст 2}

\section{Святы хлеб (сказ-легенда)}

Полацкім борам ішлі падарожныя. Іх нагнаў чалавек на возе, на якім ляжала скрыначка. Чалавек застанавіў тых людзей, якія там ішлі, і спытаўся:

- 3 якога вы боку, людзі добрыя?

Тыя адказваюць:

- 3 Ветрыншчыны.

- Ну, а я еду здалёк. 3 тых месцаў, дакуль ужо дайшла вайна. Хачу вам сказаць ось што. Калі вы хочаце, каб скончылася хутчэй вайна, то вазьміце вось гэтае.

Ён адчыніў скрыначку і вымае адтуль тры невялікія булачкі хлеба і запісачку, у якой і распавядаецца, што і як рабіць з гэтым хлебам. А рабіць ім трэба было так: аднесці гэтыя тры булачкі ў тры вёскі, у кожную па булачцы, і ўручыць сумленнай удаве; тая павінна зняць верхнюю корку 3 гэтай булачкі, а з рэшты, сабраўшы мукі, расчыніць хлеб, улажыўшы туды гэту булачку, і зноў спячы тры булачкі.

Як хлеб будзе спечаны, яна павінна сама нашча аднесці ў наступныя тры вёскі і ўручыць таксама чэсным удовам, якія павінны зрабіць тое самае і аднесці далей, туды, дзе “хлеб яшчэ не ішоў”. А тады, прыйшоўшы дамоў, яна абнашчваецца верхняй скарыначкай, якую ўзяла 3 той булачкі, якую расчыніла, каб верх быў наш.

\footnotetext{
${ }^{1}$ Мова наратываў захавана, выпраўлены асобныя знакі прыпынку, атрыбуцыя даецца паводле архіўных дакументаў.
} 
- I калі, - сказаў той чалавек з воза, - гэты хлеб дойдзе да тых месцаў, адкуль пачалася вайна, тады яна і скончыцца.

Хлеб ішоў і праз нашу вёску. Якубіха Касароўская, удава, несла. Хлеб гэты лічыўся святым, і рабіць яго павінны былі толькі чэсныя ўдовы, тайна. Бывала, неслі яго за дваццаць кіламетраў, нашча, у тую вёску, дзе ён яшчэ не ішоў, бо куды не прыдзеш, усюды пякуць. Хлеб ішоў цугам, сплашной паласой. Увесь народ памагаў. Адну бабу немцы ледзь не застрэлілі.

Дайшоў так хлеб да нямецкай граніцы, і вайна кончылася, якраз супала па часу. Людзі веруць, што святы хлеб дапамог.

Наш верх узяў над немцам.

Запісаў М. Грынблат у 1945 г. у Мінску ад М. Р. Судніка, які чуў ад сваёй маткі Марыі Міхайлаўны Суднік, 47 гадоў, няграматнай з в. Пяцюлёва Ветрынскага с/с Полацкай вобл., праз каторую таксама «хлеб ішоў». Фонд ІМЭФ. Ф. 8. Воп. 1. Спр. 1. Мінска-Маладзечанская экспедыцыя. 1945 г. Сшытак 1. Лістоў 223. Л. 217-218.

\section{Спіс выкарыстаных крыніц}

1. Гулак, Н. Да праблемы асэнсавання фальклору ваеннага часу / Н. Гулак // Беларускі фальклор: матэрыялы і даследаванні : зб. навук. прац / Нац. акад. навук Беларусі, Цэнтр даслед. беларус. культуры, мовы і літаратуры, Ін-т мастацтвазнаўства, этнаграфіі і фальклору імя К. Крапівы. - Мінск, 2019. - Вып. 6. - С. 184-194.

2. Неклюдов, С. Ю. «Этнографический факт» и его фольклорные экспликации / С. Ю. Неклюдов // Фольклор и этнография : [сб. науч. ст.] : к девяностолетию со дня рождения К. В. Чистова / Рос. акад. наук, Музей антропологии и этнографии им. Петра Великого (Кунсткамера) РАН. - СПб., 2011. - С. 40-47.

3. Лобачевская, О. А. Ритуал в повседневности войны / О. А. Лобачевская // Ноmo historicus, 2009 : гадавік антрапалаг. гісторыі / пад рэд. А. Ф. Смалянчука. - Вільня, 2010. - С. 38-53.

4. Великая Отечественная война в зеркале народной речи и фольклора : тексты, исследования / под общ. ред. Н. В. Большаковой ; сост.: Н. В. Большакова [и др.]. - Псков : Логос, 2016. - 332 с.

5. Фонд ІМЭФ. Ф. 8. Воп. 1. Спр. 9. Сш. 2. Л. 70.

6. Толстая, С. М. Обыденные предметы / С. М. Толстая // Славянские древности : этнолингвист. слов. : в 5 т. / РАН, Ин-т славяноведения и балканистики. - М., 2004. - Т. 3. - С. 487-489.

7. Минц, С. И. Фольклор Великой Отечественной войны в московских архивах / С. И. Минц // Совет. этнография. 1946. - № 2. - С. 188-192.

8. Белова, О. Обет / О. Белова // Славянские древности : этнолингвист. слов. : в 5 т. / РАН, Ин-т славяноведения и балканистики. - М., 2004. - Т. 3. - С. 446-448.

9. Традыцыйная мастацкая культура беларусаў : у 6 т. / агул. рэд. Т. Б. Варфаламеева. - Мінск, 2011. - Т. 5 : Цэнтральная Беларусь, кн. 2. - 911 с.

10. Байбурин, А. К. Ритуал в традиционной культуре : структурно-семантический анализ восточнославянских обрядов / А. К. Байбурин. - СПб. : Наука, 1993. - 240 с.

11. Лобач, У. Феномен вайны ў міфапаэтычнай карціне свету беларусаў / У. Лобач // Беларускі фальклор: матэрыялы і даследаванні : зб. навук. прац / Нац. акад. навук Беларусі, Цэнтр даслед. беларус. культуры, мовы і літаратуры, Ін-т мастацтвазнаўства, этнаграфіі і фальклору імя К. Крапівы. - Мінск, 2014. - Вып. 1. - С. 58-91.

12. Толстая, С. М. Хлеб / С. М. Толстая // Славянские древности : этнолингвист. слов. : в 5 т. / РАН, Ин-т славяноведения и балканистики. - М., 2012. - Т. 5. - С. 412-421.

13. Панченко, А. А. Исследования в области народного православия. Деревенские святыни Северо-Запада России / А. А. Панченко. - СПб. : Алетейя, 1998. - 305 с.

14. Клименко, И. Информационные бомбы и бесовская пища / И. Клименко // Мир соврем. науки. - 2012. - № 2 (11). - C. 39-47.

15. Свечников, Д. Иерусалимский хлеб, или Закваска от лукавого [Электронный ресурс] / Д. Свечников // Портал «Дивное Дивеево» : офиц. сайт Дивеев. монастыря. - Режим доступа: http://www.diveevo.ru/2/0/1/502/. - Дата доступа: 13.10.2019.

16. Панченко, А. Магические письма / А. Панченко // Современный городской фольклор : [сб. ст.] / Рос. гос. гуманитар. ун-т, Ин-т высш. гуманитар. исслед. - М., 2003. - С. 620-642.

17. Веселовский, А. Н. Опыты по истории развития христианской легенды. Эпистолия о неделе / А. Н. Веселовский // Журн. М-ва народ. просвещения. - 1876. - Ч. 184, № 3-4. - С. 50-116.

18. Лурье, В. Ф. «Святые письма» как явление традиционного фольклора / В. Ф. Лурье // Рус. литература. - 1993. № 1. - С. 144-149.

19. «Народная Библия»: восточнославянские этиологические легенды / РАН, Ин-т славяноведения ; сост. и коммент. О. В. Беловой. - М. : Индрик, 2004. - 575 с.

20. Кормина, Ж. Политические персонажи в современной агиографии: как Матрона Сталина благословляла [Электронный ресурс] / Ж. Кормина // Антропол. форум. - 2010. - № S12. - Режим доступа: http://anthropologie. kunstkamera.ru/files/pdf/012online/12_online_kormina.pdf. - Дата доступа: 12.10.2019. 


\section{References}

1. Gulak N. To the problem of interpretation of war-time folklore. Belaruski fal'klor: materyyaly i dasledavanni: zbornik navukovykh prats [Belarusian folklore: materials and research: a collection of scientific papers]. Minsk, 2019, iss. 6, pp. 184194 (in Belarusian).

2. Neklyudov S. Yu. "Ethnographic Fact" and its folklore explications. Fol'klor i etnografiya: sbornik nauchnykh statei: $k$ devyanostoletiyu so dnya rozhdeniya $K$. V. Chistova [Folklore and ethnography: collection of scientific articles: on the ninetieth birthday of K.V. Chistov]. St. Petersburg, 2011, pp. 40-47 (in Russian).

3. Lobachevskaya O. A. Ritual in the daily routine of war. Homo historicus, 2009: the annual of anthropological history. Vilnius, 2010, pp. 38-53 (in Russian).

4. Bol'shakova N. V. (ed.). The Great Patriotic War in the Mirror of folk speech and folklore: texts, research. Pskov, Logos Publ., 2016. 332 p. (in Russian).

5. Archive IAEF. Fund 8, inventory 1, case 9, notebook 2, sheet 70 (in Belarusian).

6. Tolstaya S. M. Magic things. Slavyanskie drevnosti: etnolingvisticheskii slovar' [Slavic antiquities: ethnolinguistic dictionary]. Moscow, 2004, vol. 3, pp. 487-489 (in Russian).

7. Mints S. I. Folklore of the great patriotic war in Moscow archives. Sovetskaya etnografiya [Soviet Ethnography], 1946, no. 2, pp. 188-192 (in Russian).

8. Belova O. Vow. Slavyanskie drevnosti: etnolingvisticheskii slovar' [Slavic antiquities: ethnolinguistic dictionary]. Moscow, 2004, vol. 3, pp. 446-448 (in Russian).

9. Varfalameeva T. B. (ed.) Traditional artistic culture of Belarus. Vol. 5. Central Belarus, book 2. Minsk, 2011.911 p. (in Belarusian).

10. Baiburin A. K. A ritual in traditional culture. Structural and semantic analysis of East Slavic rites. St. Petersburg, Nauka Publ., 1993. 240 p. (in Russian).

11. Lobach U. The phenomenon of war in the mythopoetic worldview of Belarusians. Belaruski fal'klor: materyyaly $i$ dasledavanni: zbornik navukovykh prats [Belarusian folklore: materials and research: a collection of scientific papers]. Minsk, 2014, iss. 1, pp. 58-91 (in Belarusian).

12. Tolstaya S. M. Bread. Slavyanskie drevnosti: etnolingvisticheskii slovar' [Slavic antiquities: ethnolinguistic dictionary]. Moscow, 2012, vol. 5, pp. 412-421 (in Russian).

13. Panchenko A. A. Research in the field of Folk Orthodoxy. Village shrines of the North-West of Russia. St. Petersburg, Aleteiya Publ., 1998. 305 p. (in Russian).

14. Klimenko I. Media bombs and food demons. Mir sovremennoi nauki [The World of Modern Science], 2012, no. 2 (11), pp. 39-47 (in Russian).

15. Svechnikov D. Jerusalem bread, or yeast from hell. Wonderful Diveevo. Available at: http://www.diveevo.ru/2/0/1/502/ (accessed 13.10.2019).

16. Panchenko A. Magic letters. Sovremennyi gorodskoi fol'klor: sbornik statei [Modern urban folklore: collection of articles]. Moscow, 2003, pp. 620-642 (in Russian).

17. Veselovskii A. N. Essays on the history of the Christian legend. Letter to the sunday Zhurnal Ministerstva narodnogo prosveshcheniya [Journal of the Ministry of Public Education], 1876, pt. 184, no. 3-4, pp. 50-116 (in Russian).

18. Lur'e V. F. "Holy Letters" as a phenomenon of traditional folklore. Russkaya literatura, 1993, no. 1, pp. 144-149 (in Russian).

19. Belova O. V. (comp.) The Folk Bible: East Slavic etiological legends. Moscow, Indrik Publ., 2004. 575 p. (in Russian).

20. Kormina Zh. Political characters in contemporary hagiography: how Saint Matrona of Moscow gave her blessing to Iosif Stalin. Antropologicheskii forum = Forum for Anthropology and Culture, 2010, suppl. 12. Available at: http:// anthropologie.kunstkamera.ru/files/pdf/012online/12_online_kormina.pdf (accessed 12.10.2019).

\section{Иформация об авторе}

Гулак Анастасия Анатольевна - кандидат филологических наук. Белорусский государственный университет культуры и искусств (ул. Рабкоровская, 17, 220007, Минск, Республика Беларусь). E-mail: rodolfina. hulak@tut.by

\section{Information about the author}

Nastassia A. Hulak - Ph. D. (Philol.). Belarusian State University of Culture and Arts (17 Rabkorovskaya Str., Minsk 220007, Belarus). E-mail: rodolfina.hulak@tut.by 